\title{
Educating the Ablest: Twenty Years Later
}

\author{
Rita R. Culross (Corresponding author) \\ School of Education, Louisiana State University \\ 301 Peabody Hall, Baton Rouge, LA 70803, United States \\ Tel: 1-225-773-0482_Email: acrita@1su.edu
}

Received: May 9, 2015 Accepted: June 8, 2015 Published: June 10, 2015

doi:10.5296/jei.v1i1.7579 URL: http://dx.doi.org/10.5296/jei.v1i1.7579

\begin{abstract}
This study examines the current lives of thirty-five individuals who participated in high school gifted programs twenty years ago. The research specifically looked at educational attainment and career goals in terms of expressed aspirations in high school, using social media and other Internet sources. Results indicated continued support for the positive life outcomes found in previous longitudinal research of the gifted.
\end{abstract}

Keywords: Gifted, Longitudinal study, Social media, Career, Education attainment

\section{Introduction}

Honored: Edmar Gardner, 17, of Macomb, youngest co-ed ever graduated from Ripon College, who will receive her degree in June after winning the highest average in the entire student body, 94.7.

The caption above appeared underneath a yellowed newspaper photo of an aunt that I uncovered while going through a collection of family photos and documents this past fall. If she were alive today, my aunt would be nearing the century mark in age. As her niece I knew her only as someone who had served as a nurse in World War II, assisted my uncle in his veterinary medical practice, and volunteered in numerous civic and charitable organizations. As a researcher with a lifelong interest in gifted students, and no prior knowledge of my aunt's early academic success, the photo reminded me of a perennial question in the field: What becomes of the youth who are identified as gifted and talented?

From Feldman's (2000) follow up of the participants of the Quiz Kids program to the studies of Terman (1947), Deary et al. (2008), Peterson et al. (2009), and Wai et al. (2009), scholars have pondered the long-term outcomes for participants in programs designed for the gifted and talented. Such studies have tended to reinforce the notion that such students exhibit, for the most part, positive life outcomes: high educational attainment, successful careers, and good personal adjustment. In general, such studies have relied on standard survey techniques 
to ascertain achievements with many of the findings based on cohorts of students from more than 30 years ago. With the evolution of societal roles, particularly those that are gender-based, as well as the evolving nature of gifted programs themselves, the question of long-term outcomes remains an active area of interest.

The current study reexamined this question using a more recent cohort of gifted youth and also added a new methodology to the mix, the use of social media to identify and track such students into adulthood.

\section{Method}

\subsection{Study Participants}

In 1991 the University of Wisconsin Extension Programs published a series of video tapes with accompanying study guides that featured talented students in gifted programs in the Wisconsin schools. The series was designed to serve as an introductory level gifted course for prospective teachers (Madison Education Extension Program, 1991). Students of various ages were shown in 12 modules illustrating various aspects of gifted programs, including counseling, mentoring, underrepresented gifted students, and different types of giftedness. A number of high school students were interviewed in the videotapes and identified by name. In all, thirty-five gifted high school students, 21 females and 14 males, were identified. All but four students were White; two students were identified as Asian-American and two as African-American. All students were in the final two years of high school when first interviewed.

\subsection{Procedures}

Study procedures were approved in advance through the researchers' university Institutional Review Board.

\subsubsection{Data Gathering - Phase I}

Two graduate students in gifted education viewed each video tape and noted each high school student identified by name. The students then transcribed verbatim the statements attributed to those students and then identified any other information provided by others about those students. Using selective coding techniques (Creswell, 2012), graduate student researchers then generated themes articulated by the students shown in the videotapes. In the case of disagreements between the two graduate students, the lead researcher resolved any discrepancies.

The two most frequently identified themes articulated by the students related to 1) educational plans and 2) future careers. Students also discussed the impact of their participation in their school's gifted program. Frequent comments regarding the latter included specifying aspects of the program they most liked, how their teachers assisted their learning, and discussions of lessons in which they were engaged. Because the researchers were most interested in the developmental trajectories of the students' lives, the second phase of the research focused on obtaining data about educational and career paths beyond high school. 


\subsubsection{Data Gathering - Phase II}

In the fall of 2011, twenty years to the date after the video tapes were released, graduate students in gifted education working in pairs conducted online searches to locate the thirty-five students identified in phase I. Thirty-one of the original students were located, representing a success rate of $88.5 \%$. (Neither of the two African-American students was located). Participants in the study were located through online searches, using names, projected colleges or careers, alumni databases, or location. In the case of some of the gifted students, their gifted programs held reunion events or created databases through which students' later whereabouts could be tracked. Other information was gleaned through search engines such as Google, Bing, or Yahoo or by searching social media such as LinkedIn, Facebook, and Twitter. Newspaper archives for cities and educational institutions provided additional information, as did employer or personal websites. At least three sources of independent information about the students were used to verify identities, and both graduate students had to agree that the information obtained was indeed linked to the original student.

Since the phase I information about the students was provided in their own words, and largely through their own eyes, their lived experience as described through information found online was viewed phenomenologically as well. In many cases available information came from posts on the individuals' personal pages at worksites, on social media such as Facebook, or on personal websites. While independent information often confirmed identities and roles in adulthood, because social media were often used as a source of information, it was felt that postings by students fit the category of lived experience as perceived by the students who were now adults.

\section{Results}

\subsection{Educational Paths}

The thirty-one gifted students $(88.5 \%)$ went on to obtain very high levels of education. The group included three individuals with Ph.D.s, five with M.D.s, three with Master's degrees, a law degree, two Bachelor of Fine Arts degrees, and 17 with other types of Bachelor's degrees. Because 12 of the students (38\%) reported obtaining advanced degrees, the total number of college degrees (i.e. 31) does not imply that every student graduated from college. Information on educational attainment was only available for 19 of the students (61\%), and it is unknown whether any of the others also completed higher education.

The colleges from which these degrees were received included some of the top institutions in the U.S., including Harvard, Cornell, MIT, the Universities of Michigan, Colorado, Chicago, and Wisconsin; as well as prestigious small colleges such as Colby and Chatham. As expected of public high school students, the top choice for these Wisconsin students was the University of Wisconsin. While many were top students as undergraduates, as evidenced by the number of individuals who went on to pursue advanced degrees, at least one student took nearly 10 years to complete his undergraduate degree. A second student who was an early college entrant at age 11 - he had been a junior in high school at age 9 -completed three undergraduate degrees before continuing on to medical school. 


\subsection{Future Careers}

A majority of the students located (18 of 31 or $58 \%$ ) were found to have pursued a career in which they articulated an interest as students. Twelve (38\%) were involved in careers in the arts, including film and television writing, directing, or producing; professional dance; freelance writing; photography; illustration; or jewelry-making. Four (12\%) who earlier indicated an interest in medicine were employed as surgeons, family practitioners, or anesthesiologists/physiatrists; while another two $(6 \%)$ who showed interest in careers as scientific researchers or scholars were working at advanced levels at major universities.

Of the remaining 13 students located only four (30\%) had pursued a path quite different from that anticipated in high school. All had been interested in pursuing careers in the performing arts; one ended up running a family business, a second chose a career in banking, a third moved into a scientific field, and a fourth sought a career in the visual arts. Perhaps this reflects the difficulty of making a living as an artist. In fact, one of the four remarked as a student

Music is something I love very much, but it's not a good career choice because there's a lot of competition out there. And to be able to make it, even to earn a salary at all, there's a lot of stress.

Nine of the students pursued careers that were perceived as related because they utilized similar skills or drew upon other interests articulated during high school. For example, while one student who became a hand surgeon never articulated an interest in medicine in high school, the student did show an interest in drawing human figures, particularly focusing on the feet. A second student who was interested in pursuing marine biology and expressed interests in environmental and social issues went on to study horticulture and work in the organic farming industry. Other students' eventual careers simply did not exist twenty years ago: web designer, CEO of a sustainable energy company, healthcare lawyer, etc. In addition, the multipotentiality some students exhibited in high school were exhibited through their pursuit of careers that combined multiple interests. One young man who expressed an interest in both biology and photography in high school went on to receive graduate degrees in molecular biology and biochemistry and to work in a 3-D lab using high-powered microscopes. A young woman who was keenly interested in ballet and pursued additional training at the Joffrey Ballet went on to receive a Ph.D. in clinical psychology, working with gymnasts and figure skaters to enhance their performance.

\subsection{Families and Adult Relationships}

Interestingly, none of the high school students interviewed addressed future relationships. (In fairness, the interviewers' questions were focused heavily on college and career choices).

What could be gleaned twenty years later largely came from personal web pages that reported marriages or sported photos of proud parents holding a newborn child, vacationing with the family, or visiting relatives around the holidays. In one student's case a parent's website provided important information tracking the personal relationships of the now adult child. At least eight of the thirty-one disclosed that they were married, with six of those posting 
discussing the activities of their children. Because educational and work data is more readily available on the Internet, there are likely far more individuals with spouses and children than was reported. With later cohorts of students more information about families and relationships will likely become more available.

\subsection{Impact of High School Gifted Program}

In the videotapes the students often expressed verbally how the gifted program had benefitted them. A student who eventually became a film producer and writer talked of the arts program as follows:

I feel well-prepared by this class and this experience to go out and compete in the field right now, whereas other people feel they have to go to college: this class has provided a strong foundation for professional theatre.

A second student who went on to do cancer research as an adult had worked for a cancer researcher as part of a mentoring project in her high school gifted program. She commented at the time:

I've always been very, very interested in science. And for me, just getting that science atmosphere is very exciting to me. So when I heard that Mrs. H. had the opportunity to match students with mentors in a setting like this ... I thought this is a wonderful opportunity ... I feel lucky that I've gotten a chance to work in this kind of setting, which I would have never had a chance to do in a normal high school setting.

A third student who attained a Ph.D. and went on to teach at the university level reflected in the videos of her appreciation for the program:

I think that being able to take classes at the university is something that is an example of a way kids can be different and have a fun time... I think having the school support that kind of activity is a really important thing ... Anyway, that the school systems can support that attitude seems, to me, a way that kids can learn and be happy.

While the research did not undercover comments made by the former students as adults addressing specifically their gifted educational experience, we did find comments that indicate the extent to which some of the now adults felt the same passion for their careers that they did for their work as students. One individual's website contained captions under pictures of his work that read: "up for air after a crazy week of focus \& insane productivity" and "long week working on a fun and challenging project." Another wrote of her career,

My personal mission is for every woman whom I teach to live fully, completely, and with serenity in her body ... When we do not nurture and stimulate the inherent growth and expansion of the body-mind, we perhaps weaken our most significant relationship ... the one we have with ourselves.

\section{Study Limitations and Directions for Future Research}

While the study illustrates how social media and other Internet-based information can be used to look at individuals' growth and development over the longer term, caution must be 
exercised in interpreting the results. The current study was relatively small ( 35 subjects) and restricted to a particular geographic area of the U.S. Students may have been selected for participation in the videotapes initially because they represented the "cream of the crop" of gifted students in the programs represented. Moreover, the reliability of information found through online searches can be suspect. While every attempt was made to confirm the accuracy of what is presented above, misinformation does exist, and even what individuals post or blog about themselves is filtered through their personal lens of what they wish to share.

Future research of larger, more diverse cohorts of students would add to the body of knowledge on long-term development of graduates of gifted programs. Combining interviews and surveys of graduates with social media methodology would enhance the accuracy and comprehensiveness of the data. Finally, ethical issues in the use of such methodologies must be carefully considered.

\section{Conclusions}

A multiple-case study of a cohort of students from a high school gifted program, using information technology as a methodology, supports previous research findings of positive life outcomes. Gifted programs do matter, particularly when viewed over the longer term.

\section{Acknowledgments}

The author acknowledges the support of Louisiana State University in the conduct of this research and in the preparation of this manuscript.

\section{References}

Creswell, J. W. (2012). Qualitative inquiry and research design: Choosing among five approaches. Sage.

Deary, I. J., Batty, G. D., Pattie, A., \& Gale, C. R. (2008). More Intelligent, More Dependable Children Live Longer A 55-Year Longitudinal Study of a Representative Sample of the Scottish Nation. Psychological Science, 19(9), 874-880. http://dx.doi.org/10.1111/j.1467-9280. 2008.02171.x

Feldman, R. D. (2000). Whatever happened to the Quiz Kids? Chicago, IL: Chicago Review Press.

Madison Education Extension Program (Producer). (1991). Educating Able Learners. [Video series]. Madison, WI: University of Wisconsin-Madison.

Peterson, J., Duncan, N., \& Canady, K. (2009). A longitudinal study of negative life events, stress, and school experiences of gifted youth. Gifted Child Quarterly, 53(1), 34-49. http://dx.doi.org/10.1177/0016986208326553

Terman, L. M. (1947). The gifted child grows up, twenty-five years follow up of a superior group: Genetic studies of genius, IV. Stanford, CA: Stanford University Press.

Wai, J., Lubinski, D., \& Benbow, C. P. (2009). Spatial ability for STEM domains: Aligning 


\section{Macrothink}

Journal of Educational Issues

ISSN 2377-2263 2015, Vol. 1, No. 1

over 50 years of cumulative psychological knowledge solidifies its importance. Journal of Educational Psychology, 101(4), 817. http://dx.doi.org/10.1037/a0016127

\section{Copyright Disclaimer}

Copyright for this article is retained by the author(s), with first publication rights granted to the journal.

This is an open-access article distributed under the terms and conditions of the Creative Commons Attribution license (http://creativecommons.org/licenses/by/3.0/). 